\title{
Development of Teaching Materials to Biographical Text Based on Ethical Value for Junior High School Student
}

\author{
Suhariyanti \\ Department of Indonesian Language Education Postgraduate \\ School Universitas Negeri Medan Medan, Indonesia \\ suhariyanti_unimed@yahoo.com
}

\author{
Malan Lubis \\ Lecturer of Indonesian Language Education Postgraduate \\ School Universitas Negeri Medan Medan, Indonesia
}

\author{
Khairil Ansari \\ Lecturer of Indonesian Language Education \\ Postgraduate School Universitas Negeri \\ Medan Medan, Indonesia \\ Khairi1728@unimed.ac.id
}

\begin{abstract}
This study aims to determine the results of the development of teaching materials biography ethics-based text by students of class VIII MTsN 2 Medan. The teaching materials developed are modular. This type of research is a developmental study based on the development model of Borg and Gall. With the test subjects consisting of material experts, design experts, Indonesian teachers, and students of grade VIII MTsN 2 Medan. The result of the research shows that (1) validation from the material experts include the average content of the average obtained $89.84 \%$ and the valuation of the language aspect obtained the average $89.42 \%$ (2) Validation of design experts with an average of $84.58 \%$ (3) teacher response earns an average of $85.83 \%$ (4) Individual trial obtains an average of $75 \%$ (5) small group trials obtained an average of $83.56 \%$ (6) unlimited field testing obtained an average of $94.92 \%$. The learning results of producing biographical texts before using the module earned 70.65 while the test result produced biographical text using modules increased by obtaining 81.09. Difference gained 10.44 from before and after using module.
\end{abstract}

Keywords - teaching materials, biographical text, ethical value.

\section{INTRODUCTION}

The selection and development of teaching materials is a demand for teachers in their professional activities. This is because teaching materials are independent, meaning that a teacher can find, search, compile and develop teaching materials that are appropriate to the needs of students by not going out on the standard content path..

Teaching materials are all forms of teaching materials used to assist teachers / instructors in carrying out teaching and learning activities in the classroom. The material in question can be in the form of written material or unwritten material. $^{[1]}$

Indonesian language learning in the 2013 curriculum refers more to mastery and ability, understanding, analyzing, composing, observing, communicating and identifying and comparing a text. One of the text-based learning in the 2013 class VIII junior high school curriculum is biographical text. Biography is writing about a person's life. Biographical text is a text that contains a story or description of a person's life. A biography is more complex than just a list of birth dates and job data. ${ }^{[2]}$ Biography also tells about the feelings involved in experiencing these events which show the character meant personal experience. The texts in the 2013 curriculum are expected to be a great opportunity that can be used by educators, especially teachers to develop quality teaching materials and be able to instill the values of life in students, especially in biographical texts.

The development of teaching materials in biographical texts is carried out to provide new understanding to students in expressing the life values of figures that can be exemplified including ethical values.

Ethical values are values that are viewed in terms of character, character, morality or customs, related to the concept that is owned by individuals or groups to assess whether the actions that have been done are wrong or true, bad or good that can be measured by reason. ${ }^{[3]}$

The importance of cultivating ethical values in students, basically to equip or apply the value of good, bad, is wrong in terms of character, character, decency or custom which functions as a determinant and determinant of an act carried out by humans. Whether the act will be judged good or bad can be measured by reason.

Researcher's observations from the student's handbook, that in the textbook students have not reflected the ethical values in it. In books students tend to focus on mastering the material (cognitive) only. If the teaching materials used by students are developed based on ethical values, the participants not only gain knowledge (cognitive), but students will get motivation and stimulate to be more interested in the learning process in order to have a positive influence on their psychological. 
Important values related to ethics are courtesy, tolerance, helping, honesty, integrity, discipline and positive thinking. For this reason, the writer formulates a form of research on the Development of Biographical Text Learning Materials Based on Ethical Values, the end result is in the form of modules as a companion material for learning junior high school students.

\section{METHOD}

This research is done in junior high school for grade VIII (MTsN 2 Medan). The methods used in this research is the development of methods (Research and Development/R\&D).

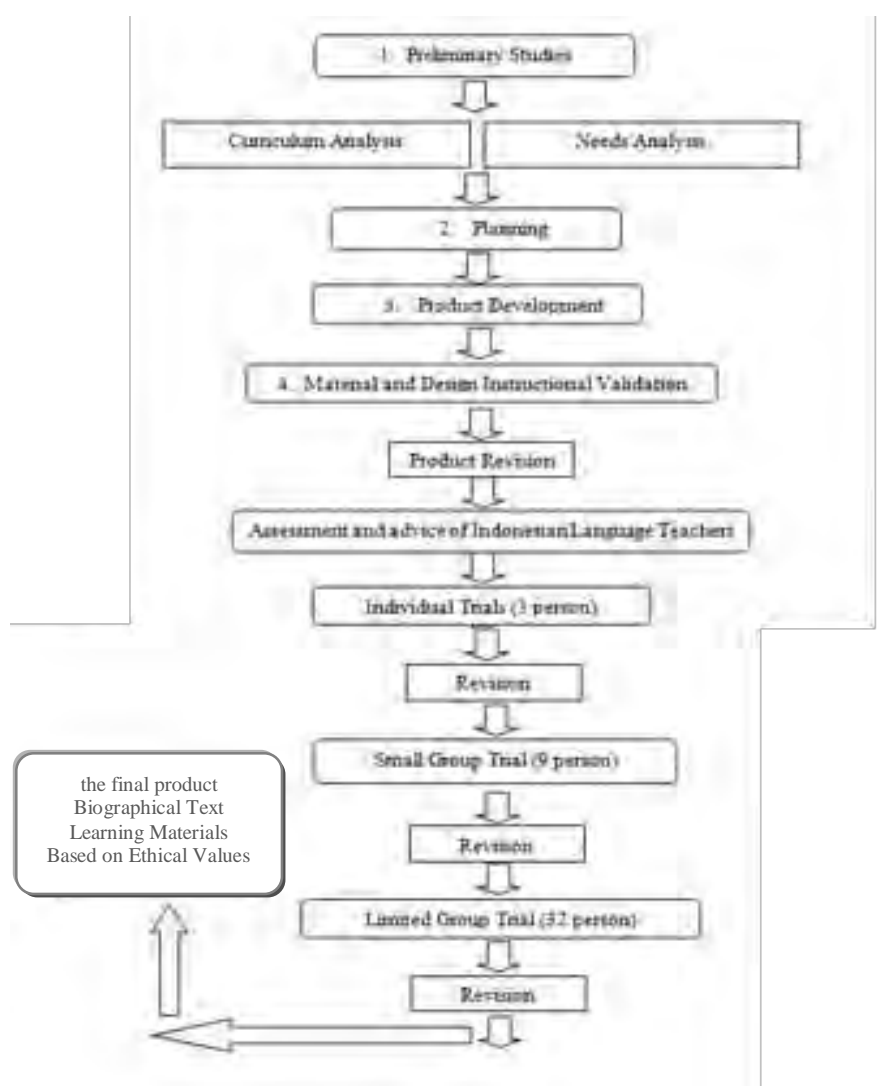

Fig 1. Development Flow Borg \& Gall

The research method is based on adaptations made Borg \& Gall. There are ten steps of the research put forward by Borg and Gall, namely: (1) research and information gathering, (2) planning, (3) developing initial products, (4) initial field testing, (5) product revision, (6) trial field, (7) revision, (8) operational field test, (9) final product revision, (10) product dissemination and implementation

\section{RESULTS}

\section{A. The Process of Developing Teaching Materials}

The front cover contains the title of the module, the author's identity, the identity of the supervisor and the subject matter. The cover of the module is also equipped with 2 logos, i.e. logos graduate school of the State University of Medan (Unimed) and 2013 Curriculum logo. The module cover is also equipped with a representative biography figure. The images in this module relate to the basis of modules developed with ethical values. In addition to conformity with the base, this module cover image also aims to attract the attention of junior high school students.

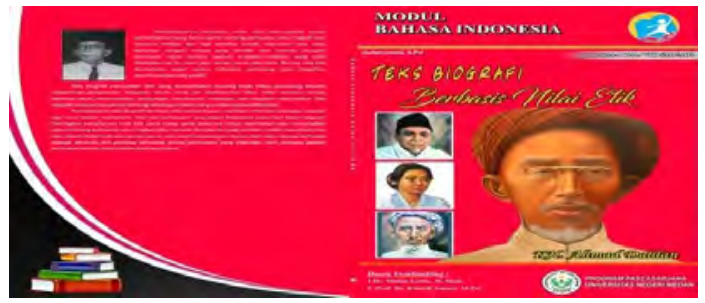

Fig 2. Front Cover and Back Cover

Learning activity contains the title of the activity, the basic competence (KD) and indicators of learning. It is aimed to let the students know the basic competencies and indicators that will be achieved in the process of learning by using this module. In this module there are 3 learning activities designed 2 times for each learning activity.

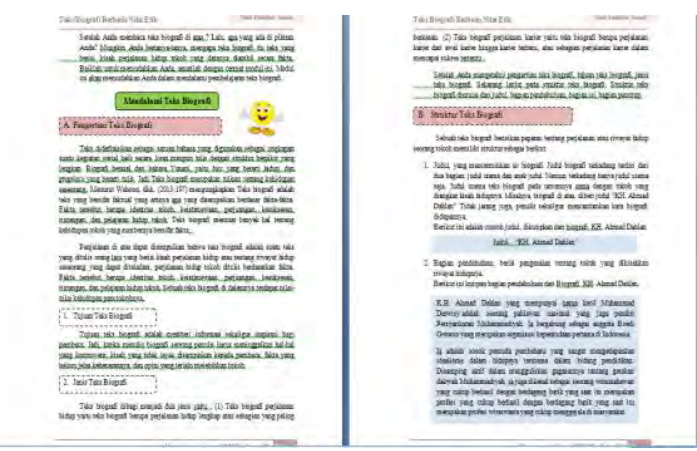

Fig 3. Module Learning Activities

The developed module contains 6 examples of biographical texts by raising national education figures in the book of World Education Figures by Suyitno (2009).

In activity 1 before entering the core student's method is introduced to the character of K.H. Ahmad Dahlan along with his ethical values. K.H. Ahmad Dahlan is a reformer youth who has put Idealism in his life, especially in the field of education. 

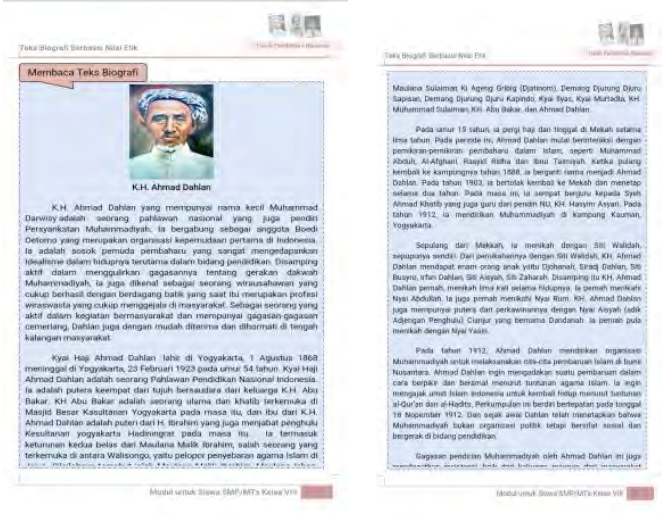

Figure 4. Module examples of biographical

A matter of practice located at the end of the learning activity after the summary. This question aimed to see the student's mastery to the materials presented. Exercise module in the form of essay test. The practice of writing biographical texts is equipped with illustrations of the most important figures in Indonesia. This picture is intended to make students easy to understand in writing their ideas in writing.

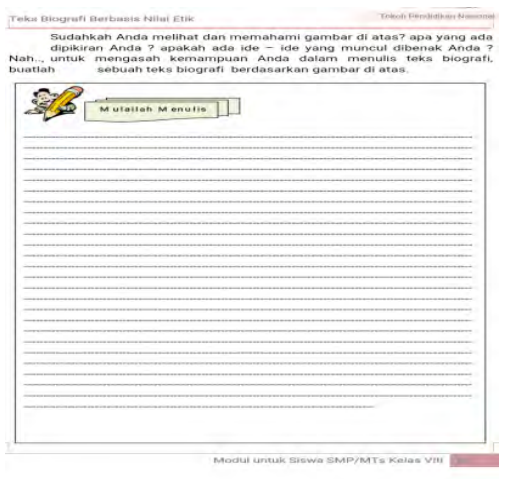

Fig 5. Exercise

\section{B. Feasibility of Teaching Materials}

Feasibility of teaching materials is obtained from the results of validation and assessment provided by material experts and design experts. Through the results of the assessment, the data obtained is then analyzed to determine whether or not the teaching materials are in the form of ethics-based biography text modules to be tested through the feasibility process of teaching materials. The process for obtaining the feasibility of teaching materials is divided into two, namely material feasibility and design feasibility.
TABLE 1.

The results of the Validation by an expert

\begin{tabular}{|c|c|c|c|}
\hline No & Aspects that are Assessed & $\begin{array}{c}\text { The } \\
\text { average } \\
\text { Percentage } \\
(\%)\end{array}$ & Criteria \\
\hline 1 & $\begin{array}{r}\text { Eligibility Of } \\
\text { Contents Aspects }\end{array}$ & 89.84 & Decent \\
\hline 2 & Presentation Aspect & 90,38 & Very Decent \\
\hline 3 & Linguistic Aspects & 89,42 & Decent \\
\hline 4 & Design aspects & 84,58 & Decent \\
\hline
\end{tabular}

Based on the table above can be concluded the results of the overall module based on ethical values developed is in a Decent category with a total percentage of $89,84 \%$. Aspects of feasibility with an average of $90,38 \%$, presentation aspect language aspect $89,42 \%$ and $84,58 \%$ aspect of graphic. Based on the assessment of material experts and design experts, it can be concluded that the teaching materials for ethics-based biographical texts designed for junior high school students are categorized as very valid and feasible to be used in the learning process.

TABLE 2. Data on Indonesian Language Teachers' response to teaching materials

\begin{tabular}{|c|c|c|c|}
\hline No. & Indicator & $\begin{array}{l}\text { Score } \\
\text { average } \\
(\%)\end{array}$ & Criteria \\
\hline 1 & $\begin{array}{l}\text { The overall appearance of the } \\
\text { module is interesting }\end{array}$ & $88 \%$ & Good \\
\hline 2 & $\begin{array}{l}\text { The language used in the } \\
\text { module is easy to understand }\end{array}$ & $100 \%$ & Very Good \\
\hline 3 & $\begin{array}{l}\text { The presentation of the material } \\
\text { in the module is systematically } \\
\text { arranged }\end{array}$ & $100 \%$ & Very Good \\
\hline 4 & $\begin{array}{l}\text { The material in the module is in } \\
\text { accordance with the learning } \\
\text { objectives }\end{array}$ & $75 \%$ & enough \\
\hline 5 & $\begin{array}{l}\text { Use of images in a clear } \\
\text { module The use of images in } \\
\text { the module is clear }\end{array}$ & $100 \%$ & Very Good \\
\hline 6 & $\begin{array}{l}\text { Learning activities stimulate } \\
\text { critical thinking skills }\end{array}$ & $88 \%$ & Good \\
\hline 7 & $\begin{array}{l}\text { The types of activities in the } \\
\text { module vary }\end{array}$ & $88 \%$ & Good \\
\hline 8 & $\begin{array}{l}\text { Latest information in the } \\
\text { module in accordance with the } \\
\text { development of science and } \\
\text { technology }\end{array}$ & $88 \%$ & Good \\
\hline 9 & $\begin{array}{l}\text { Use of symbols in accordance } \\
\text { with existing rules }\end{array}$ & $88 \%$ & Good \\
\hline 10 & $\begin{array}{l}\text { The module helps students } \\
\text { understand biography text } \\
\text { learning material }\end{array}$ & $100 \%$ & Very Good \\
\hline 11 & $\begin{array}{l}\text { Modules differ from usual } \\
\text { teaching materials }\end{array}$ & $88 \%$ & Good \\
\hline 12 & $\begin{array}{l}\text { Modules can be studied } \\
\text { independently by students }\end{array}$ & $88 \%$ & Good \\
\hline 13 & $\begin{array}{l}\text { The module trains students to } \\
\text { enrich students' knowledge }\end{array}$ & $88 \%$ & Good \\
\hline 14 & $\begin{array}{l}\text { Modules make it easier for } \\
\text { teachers to evaluate students }\end{array}$ & $88 \%$ & Good \\
\hline
\end{tabular}




\begin{tabular}{|l|l|l|l|}
\hline 15 & $\begin{array}{l}\text { Modules make it easier for } \\
\text { students to express their } \\
\text { opinions in oral or written form }\end{array}$ & $100 \%$ & Very Good \\
\hline & Score & $85,83 \%$ & Good \\
\hline
\end{tabular}

The results of the teacher's response to the instructional material for biographical texts based on ethical values developed had a total percentage of $85.83 \%$ with a "good" criterion.

Each assessment result will be classified with the percentage criteria table the appearance of indicators on the teaching material as follows:

\begin{tabular}{|c|c|c|}
\hline No. & Answer & Score \\
\hline A & Very Good & $90-100 \%$ \\
\hline B & Good & $80-89 \%$ \\
\hline C & Enough & $60-79 \%$ \\
\hline D & Low & $40-59 \%$ \\
\hline E & Very Low & $<40 \%$ \\
\hline
\end{tabular}

(Arikunto, 2013:46)

The results of responses from students of $\mathrm{MTsN} 2$ Medan concluded that the instructional material in the form of a biographical text module based on ethical values that had been developed was declared feasible and met the needs with the overall criteria of "very good". This means that the instructional material developed has increased development and can meet the demands of learning needs. For more details, empirical data acquisition results can be seen in Figure 4.1 below.

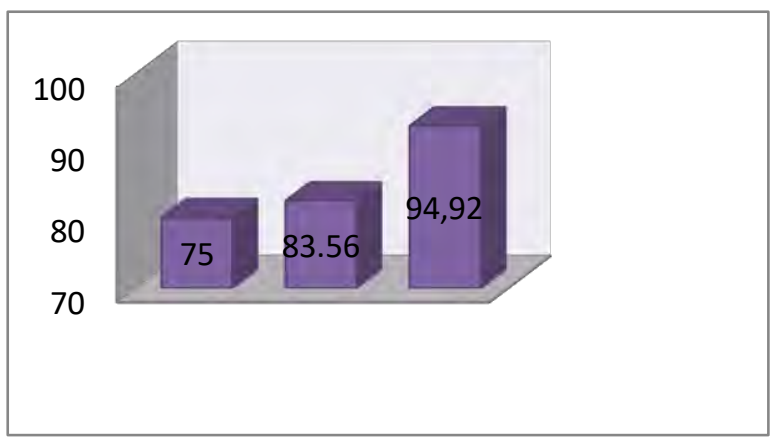

\section{Effectiveness of Teaching Material Development}

The effectiveness of ethics-based modules is known through learning outcomes tests. The form of the test used to test the effectiveness of the module is the essay test. This essay test was conducted in two stages, namely pretest and posttest. The purpose of the pretest is to find out the average initial ability of students before using the module in learning. While posttest aims to determine the ability of students after the use of modules in learning.
TABLE 3

Summary of Average Pretest and Posttest Values

\begin{tabular}{|c|c|c|}
\hline Group & $\begin{array}{c}\text { Average } \\
\text { value }\end{array}$ & Difference \\
\hline (Pretest) & 70,65 & 10,44 \\
\hline (Posttest) & 81,09 & \\
\hline
\end{tabular}

The table above shows that the difference from the pretest to posttest value obtained is 10.44 with an average pretest of 70.65 on the criteria of "enough" and the average posttest of 81.09 on the criteria of "good". It can be concluded that learning to use instructional materials based on ethical values can improve student learning outcomes in Indonesian language learning, especially on biographical text material.

\section{CONCLUSION}

The results of the development of teaching materials for ethics-based biography texts based on needs analysis states that the development of teaching materials is needed by teachers and students in the learning process to improve the quality of learning and align learning objectives with the latest curriculum provisions by the government and increase student interest in learning.

\section{REFERENCES}

[1]. Haryanto . Nilai-nilai yang penting terkait dengan etika. Jakarta: Jurnal Psikologi Ulayat, Vol. 4, No. 1/Juni 2017, pp. 1-10.

[2]. Hernawan, Pengembangan Kurikulum dan Pembelajaran, Jakarta: Universitas Terbuka. 2008. Pengembangan Kurikulum dan Pembelajaran. Universitas Terbuka. Jakarta.

[3]. Mega Putri. Kemampuan Menulis Teks Biografi Siswa Kelas VIII SMP Negeri 2 Kota Solok. Jurnal Bahastra, Oktober 2016, Volume XXXVI, Nomor 1, hlm 1-13.

[4]. Tegeh, et al, Model Penelitian Pengembangan. Yogyakarta: Graha Ilmu, 2014, pp.7.

[5]. Wahono, et al. Mahir Berbahasa Indonesia. Mahir Berbahasa Indonesia. Jakarta: Erlangga.2013,pp 8

[6]. Waluyo, Budi. Bahasa dan Sastra Indonesia. Solo: PT Tiga Serangkai Pustaka Mandiri, 2014,pp. 34. 